\title{
Searching for Bright Lines in the Trump Presidency
}

\author{
John M. Carey, Gretchen Helmke, Brendan Nyhan, Mitchell Sanders, and Susan Stokes
}

\begin{abstract}
Is American democracy under threat? The question is more prominent in political debate now than at any time in recent memory. However, it is also too blunt; there is widespread recognition that democracy is multifaceted and that backsliding, when it occurs, tends to be piecemeal. To address these concerns, we provide original data from surveys of political science experts and the public measuring the perceived importance and performance of U.S. democracy on a number of dimensions during the first year-and-a-half of the Trump presidency. We draw on a theory of how politicians may transgress limits on their authority and the conditions under which constraints are self-enforcing. We connect this theory to our survey data in an effort to identify potential areas of agreement - bright lines — among experts and the public about the most important democratic principles and whether they have been violated. Public and expert perceptions often differ on the importance of specific democratic principles. In addition, though our experts perceive substantial democratic erosion, particularly in areas related to checks and balances, polarization between Trump supporters and opponents undermines any social consensus recognizing these violations.
\end{abstract}

We hope all dangers may be overcome; but to conclude that no danger may ever arise, would itself be extremely dangerous.

—Abraham Lincoln, Lyceum Address

s American democracy eroding? For many scholars, the answer is a resounding yes. ${ }^{1}$ Public support for democracy may be slipping, as Foa and Mounk ${ }^{2}$ argue. The commitment of political leaders to democratic norms may also be declining, as Levitsky and Ziblatt (2018) contend, threatening the stability of liberal democracy.
These threats are seemingly being exacerbated at both the mass and elite level by partisan polarization (Fishkin and Pozen 2018) and a cultural backlash that has fueled authoritarian-populist movements in the United States and Europe (Norris and Inglehart 2018).

It is too early to say whether the long-term quality of democracy in the United States will suffer. Our political system and civil society retain formidable sources of resilience such as wealth and democratic longevity. But signs of potential degradation are everywhere.

A list of permanent links to Supplemental Materials provided by the authors precedes the References section.

*Data replication sets are available in Harvard Dataverse at: https://doi.org/10.7910/DVN/IYWXMF

John M. Carey is the Wentworth Professor in the Social Sciences at Dartmouth College, (John.M.Carey@dartmouth.edu).

Gretchen Helmke is Professor of Political Science at the University of Rochester (gretchen.helmke@rochester.edu).

\begin{abstract}
Brendan Nyhan is Professor of Public Policy in the Gerald R. Ford School of Public Policy at the University of Michigan (bnyhan@umich.edu).
\end{abstract}

Mitchell Sanders is Director of Survey Research for Bright Line Watch (survey@brightlinewatch.org).

Susan Stokes is the Tiffany and Margaret Blake Distinguished Service Professor of Political Science and Director of the Program on Democracy at the University of Chicago (sstokes@uchicago.edu).

Bright Line Watch surveys were generously funded by grants from the Democracy Fund and the William and Flora Hewlett Foundation. The authors are extremely grateful to YeonKyung Jeong for outstanding research assistance, and to three anonymous reviewers. All errors in the manuscript are the authors' sole responsibility. 
We present original survey research we conducted among the general public and among political science experts to monitor potential democratic erosion in the United States. Our empirical findings are fourfold. First, although there is still broad public consensus over democratic priorities, Americans are deeply divided over the quality of their democracy. Second, that divide is growing. Third, many of the principles that the public most values about democracy differ from those prioritized by the experts. Fourth, the pace and sequence of democratic erosion identified by experts over the last year-and-a-half broadly fits with narrative accounts of democratic backsliding in other parts of the world. Taken together, the patterns we uncover underscore why polarization presents a unique challenge to democratic resilience, and illuminate why the numerous transgressions against democracy identified by experts since the Trump administration took office have seemingly not provoked commensurate public outrage.

\section{Democracy and the Compound Consensus}

In order to examine the quality of American democracy, the severity of threats to it, and the sources of its resilience, we conducted the Bright Line Watch (BLW) expert and public surveys. These surveys measure the perceived importance of key democratic principles (described later) and the extent to which they are perceived as being upheld in the United States.

This measurement approach was inspired by the theoretical framework developed by Weingast (1997), who links citizens' values, beliefs, and perceptions directly to democratic stability. Harkening back to Locke (1689), Weingast underscores that constraints on governments will be ineffective-mere parchment barriersunless they are backed up by a societal commitment to police and defend them. ${ }^{3}$ By this account, two critical conditions must be met for politicians to obey limits on their authority and hence for democracy to be selfenforcing:

- First, there must be agreement among citizens that a particular principle or right is so crucial that its violation would amount to a fundamental breach of the rule of law.

- Second, there must be consensus among citizens that a transgression has occurred.

The conditions for this compound consensus are demanding. For self-enforcement to take place, perceptions of a transgression of such bright lines must be shared not only by those citizens who are directly affected but also by third parties, possibly including rivals, who recognize a threat to their own rights and interests
(Weingast 1997, 251-252). Self-enforcement effectively constrains political authority only when a consensus motivates third-party actors to police violations by political officials. As Weingast puts it, "if citizens hold different views about limits on the state- or if they are unwilling to defend these limits - then the sovereign can violate these limits and retain sufficient support to survive. In this case, limits on the sovereign are not self-enforcing" (Weingast 1997, 246).

This theoretical framework helps us consider how the American political system might limit a president who frequently signals his disdain for legal, constitutional, and normative constraints. Moving from theory to the real world, of course, the precise level of societal consensus required to constrain the president becomes an empirical question. Moreover, the challenge for any contemporary application of Weingast's theory is that the potential set of rights and principles a political leader might violate is vast (Dahl 1973). The original study focuses on taxation, confiscation of property, and religious liberty during England's Glorious Revolution. The potential set of principles one might regard as essential for American democracy today is more extensive, including not only free and fair elections, but whether the playing field remains level, which itself hinges on a variety of other rights and protections (Coppedge et al. 2011).

We thus designed the BLW surveys to measure the status and perceived importance of this broader set of formal institutions and informal practices that might be regarded as essential to democracy in the contemporary United States. Over the past year-and-a-half, our surveys have enabled us to track: (a) the degree of consensus about democratic institutional priorities that exists among experts and the public and (b) the degree of consensus that exists within each group that transgressions of important democratic principles have occurred. Together, these two dimensions point toward potential arenas of coordination in defense of democracy, but they also indicate obstacles to such coordination. Thus they provide a nuanced picture of sources of resilience-and vulnerability-in American democracy.

The next section of this paper describes the surveys we use to measure democratic priorities and evaluations of democratic performance. We then present data on priorities and performance assessments from expert respondents and from representative samples of the American public. Among the public, we compare the attitudes of supporters and opponents of President Trump, and we illustrate how assessments have changed during his first year-and-a-half in office. Respondents in the public sample agree much more about what matters for democracy than they do about whether those ideals are being fulfilled or violated. 


\section{Motivation}

We begin by considering the broad evidence of decline in the status of U.S. democracy. Our May 2017 survey of political scientists at American universities asked respondents to rate the quality of U.S. democracy on a 0-to-100 scale at nine different periods in the country's history from 1800 to 2015. In each of the six expert surveys we conducted from February 2017 to July 2018, we also solicited a comparable 0-to-100 rating for U.S. democracy at the time of the survey.

Figure 1 shows the mean responses from these surveys, with $95 \%$ confidence intervals, plotted against analogous ratings of U.S. democracy from the Varieties of Democracy (V-Dem) project, which is the current state of the art in cross-national and over-time ratings of democracy and its components (Coppedge et al. 2018; Pemstein et al. 2018). ${ }^{4}$

The retrospective ratings from our experts correspond closely with those of V-Dem's analysts. Both report steady increases in the quality of U.S. democracy during the nineteenth and twentieth centuries. After registering high scores in recent decades, both show sharp declines in their most recent observations, which cover 2016 and 2017 for V-Dem and 2017 and 2018 for BLW. ${ }^{5}$

It is useful to consider why both sets of experts provided the ratings they did. As we write elsewhere about the Bright Line Watch Expert Survey Wave 2 (2017),

The period from 1850-1900 saw the Civil War, the abolition of slavery, the Civil Service Act, and the beginning of the Progressive Era reforms, but also the abandonment of Reconstruction and the establishment of Jim Crow in the South (1850-1900). The period from 1900-1950 saw the ratification of the 19th Amendment to the Constitution guaranteeing women's voting rights as well as the vast expansion of the federal welfare state under Roosevelt's New Deal and the first achievements of the civil rights movement. The time lapses in our survey question shortened at this point. Between 1950 to 1975 , the country experienced the high water mark of the civil rights movement, including landmark civil rights legislation in 1957 and 1964 and the Voting Rights Act of 1965. The average rating for US democracy rose more steeply during this 25 -year span than it did on average during the prior 50-year intervals.

Ratings for U.S. democracy rose correspondingly. Subsequently, as they approach the top of the scale, the assessments level off somewhat over the next four decades between 1975 and 2015, a period that spanned administrations with distinct governing ideologies ranging from Ronald Reagan and George W. Bush to Bill Clinton and Barack Obama. The most recent ratings, however, show a sharp decline under the Trump administration. ${ }^{6}$

Together, the BLW surveys and V-Dem ratings provide the most systematic evidence to date of the serious concern among experts about the current state of American democracy. We turn now to a closer examina-

\section{Figure 1 \\ Ratings of U.S. democracy from V-Dem and Bright Line Watch}

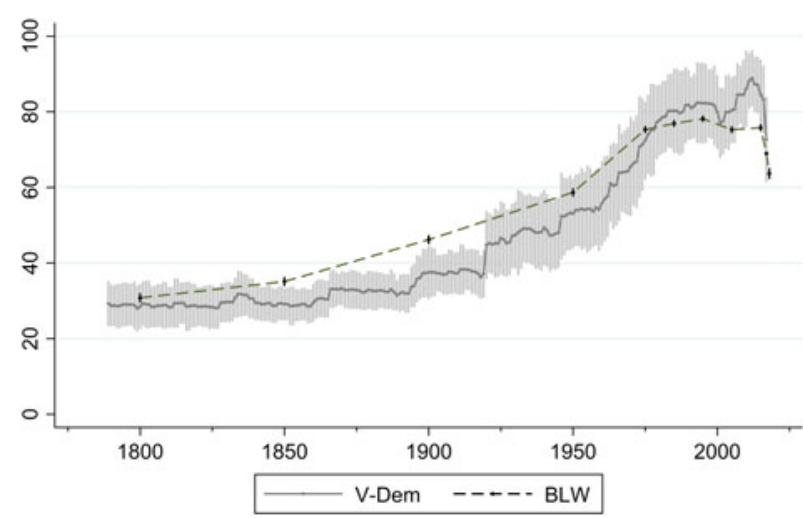

tion of the areas in which BLW experts perceive erosions in performance.

\section{How We Measure Democratic Principles and Performance}

The core of the BLW surveys is a list of 27 statements of democratic principles. ${ }^{7}$ Other research-such as the foundational Przeworski et al. (2000) study of the effects of economic development on regime change-usefully employs a thin, election-centered definition of democracy. Our interest in identifying the nature and scope of potential democratic erosion in the United States requires a different approach. We consider a broad array of principles that contribute to the overall stability and performance of American democracy. These allow us to identify potential threats to democracy, which rarely manifest en masse against a political system as a whole, but rather through the piecemeal erosion of its pillars (Bermeo 2016; Levitsky and Ziblatt 2018).

We present the full set of statements, which we have grouped into categories, below. ${ }^{8}$ These have been measured in six surveys, Wave 1 (February 2017), Wave 2 (May 2017), Wave 3 (September 2017), Wave 4 (January 2018), Wave 5 (April 2018), and Wave 6 (July 2018).

All our surveys are internet-based. In all waves, we draw on a sample of expert respondents. We collected e-mail contacts for all faculty listed on the websites of all political science departments at U.S. universities from which at least one member attended the 2016 American Political Science Association annual meetings. We sent e-mail invitations to these faculty (removing from the list in each wave any faculty who request removal or whose invitations bounced back in the previous wave). Those who agree to participate are directed to an online survey conducted using Qualtrics software. ${ }^{9}$ Waves 3-6 
additionally include a representative sample of the American public assembled by YouGov. ${ }^{10}$ The designs of the surveys are summarized in table 1 .

The statements of democratic principles at the center of all our surveys are as follows:

\section{ELECTIONS}

- Elections are conducted, ballots counted, and winners determined without pervasive fraud or manipulation.

- Citizens have access to information about candidates that is relevant to how they would govern.

- The geographic boundaries of electoral districts do not systematically advantage any particular political party.

- Information about the sources of campaign funding is available to the public.

- Public policy is not determined by large campaign contributions.

- Elections are free from foreign influence.

\section{VOTING}

- All adult citizens have equal opportunity to vote.

- All votes have equal impact on election outcomes.

- Voter participation in elections is generally high.

\section{RIGHTS}

- All adult citizens enjoy the same legal and political rights.

- Parties and candidates are not barred due to their political beliefs and ideologies.
- Government protects individuals' right to engage in unpopular speech or expression.

- Government protects individuals' right to engage in peaceful protest.

- Citizens can make their opinions heard in open debate about policies that are under consideration.

\section{PROTECTIONS}

- Government does not interfere with journalists or news organizations.

- Government effectively prevents private actors from engaging in politically-motivated violence or intimidation.

- Government agencies are not used to monitor, attack, or punish political opponents.

\section{ACCOUNTABILITY}

- Government officials are legally sanctioned for misconduct.

- Government officials do not use public office for private gain.

- Law enforcement investigations of public officials or their associates are free from political influence or interference.

\section{INSTITUTIONS}

- Executive authority cannot be expanded beyond constitutional limits.

- The legislature is able to effectively limit executive power.

\section{Table 1}

\section{Bright Line Watch surveys: Waves 1 to 6}

\begin{tabular}{|c|c|c|c|c|c|c|}
\hline & $\begin{array}{c}\text { Wave } 1 \\
\text { February } \\
2017\end{array}$ & $\begin{array}{c}\text { Wave } 2 \\
\text { May } 2017\end{array}$ & $\begin{array}{c}\text { Wave } 3 \\
\text { September } \\
2017\end{array}$ & $\begin{array}{c}\text { Wave } 4 \\
\text { January } \\
2018\end{array}$ & $\begin{array}{c}\text { Wave } 5 \\
\text { April } \\
2018\end{array}$ & $\begin{array}{c}\text { Wave } 6 \\
\text { July } \\
2018\end{array}$ \\
\hline $\begin{array}{l}\text { Expert sample size } \\
\quad \text { (and response rate) }\end{array}$ & $\begin{array}{l}1,569 \\
(16 \%)\end{array}$ & $\begin{array}{l}1,126 \\
(12 \%)\end{array}$ & $\begin{array}{l}1,055 \\
(12 \%)\end{array}$ & $\begin{array}{l}1,066 \\
(12 \%)\end{array}$ & $\begin{array}{c}935 \\
(10 \%)\end{array}$ & $\begin{array}{c}679 \\
(8 \%)\end{array}$ \\
\hline Public sample size & - & - & 3,000 & 2,000 & 2,000 & 2,000 \\
\hline Total \# of statements & 19 & 29 & 27 & 27 & 27 & 27 \\
\hline \# of statements per expert respondent & 19 & 15 & 12 & 14 & 14 & 14 \\
\hline \# of statements per public respondent & - & - & 9 & 14 & 14 & 14 \\
\hline Performance battery & Yes & Yes & Yes & Yes & Yes & Yes \\
\hline Importance battery & Yes & - & Yes & - & - & - \\
\hline U.S. rating, $0-100$ scale & - & Yes & Yes & Yes & Yes & Yes \\
\hline Other rating, $0-100$ scale & - & $\begin{array}{l}\text { U.S. } \\
\text { historical }\end{array}$ & - & International & - & \\
\hline
\end{tabular}


- The judiciary is able to effectively limit executive power.

- The elected branches respect judicial independence.

\section{DISCOURSE}

- Even when there are disagreements about ideology or policy, political leaders generally share a common understanding of relevant facts.

- Elected officials seek compromise with political opponents.

- Political competition occurs without criticism of opponents' loyalty or patriotism.

In each survey wave, we measure performance by presenting respondents with a randomly generated subset of statements (except for the initial wave, when all statements were seen by all respondents) and asking, for each, "How well do the following statements describe the United States as of today?" with the following response options:

- The U.S. does not meet this standard.

- The U.S. partly meets this standard.

- The U.S. mostly meets this standard.

- The U.S. fully meets this standard.

- Not sure.

In Waves 1 and 3, prior to the performance battery, we asked participants "How important are these characteristics for democratic government?" with the following response options for each statement:

- Not relevant. This has no impact on democracy.

- Beneficial. This enhances democracy, but is not required for democracy.

- Important. If this is absent, democracy is compromised.

- Essential. A country cannot be considered democratic without this.

Waves 2, 4, 5, and 6 omitted the importance battery. ${ }^{11}$ In Wave 2, we instead asked respondents to rate the overall quality of U.S. democracy at nine historical dates using a $0-100$ scale, while in Wave 4 we asked for ratings of current democracy in twelve countries other than the United States on the same 0-100 scale. In each survey wave, after completing the U.S. performance battery, we ask respondents to rate the overall quality of democracy in the United States at present. ${ }^{12}$

\section{Testing for a Consensus on Democratic Priorities}

Which features of democracy do experts and citizens most value and to what degree are those values shared between groups?
Figure 2 shows the percentage of respondents in our expert and public surveys who rated each principle as either essential or important (as opposed to unimportant or merely beneficial) to democracy. ${ }^{13}, 14$ The statements are listed in descending order of rating by experts. Ratings are substantially correlated between the groups $(r=.77)$, yet consensus between experts and the public tends to be stronger around the principles that experts rated as less important and weaker around many of the principles that experts prized more. A clear exception to this is fraud-free elections, on which both groups place the highest value. As Fearon has noted,

Citizens may have disparate views of the government's performance, but whether elections are held according to schedule is publicly observable. The institution of commonly understood electoral rules and procedures thus allows the citizen to credibly threaten mass protest if the ruler does not provide them with the means of aggregating their diverse observations (Fearon 2011, 1662).

Similarly, most experts (96\%) and the public (89\%) agree on the importance of equal voting rights, sanctions for misconduct ( $91 \%$ experts, $84 \%$ public), and constitutional limits on the executive ( $88 \%$ of experts, $83 \%$ of the public).

As we move lower in the figure, there is also agreement between experts and the public about the importance of elections being free of foreign influence ( $82 \%$ of experts, $83 \%$ of the public), as well as several additional principles related to voting and accountability. Both groups tend to place institutional checks, such as judicial independence, and the ability of the courts and legislature to check the executive somewhere in the middle of the pack. Among experts, the secondary status of these principles may reflect recognition that the system of checks and balances embodied in the U.S. Constitution represents only one of the many possible institutional designs among democracies (Lijphart 1977; Shugart and Carey 1992; Powell 2000; Elkins, Ginsburg, and Melton 2009). Experts value institutional checks more highly than does the public as a whole, whereas among principles less valued by both groups, expert assessments tend to be lower. In addition, both groups concur that many of the informal norms of political behavior - a common understanding of facts, that politicians seek compromise, and that they do not impugn the patriotism of their opponents—rank lower in importance among our set of democratic principles.

However, experts and the public differ in the perceived importance of many basic rights and protections. Almost every expert perceives the First Amendment rights to protest $(98 \%)$ and of freedom of the press $(97 \%)$ to be as essential as free and fair elections. But these views are less widely shared among the public (82\% for the right to protest, $73 \%$ for freedom of the press). Similar gaps pertain for free speech $(97 \%$ experts, 


\section{Figure 2 \\ Expert and public responses to "How important are these characteristics for democratic government?"}

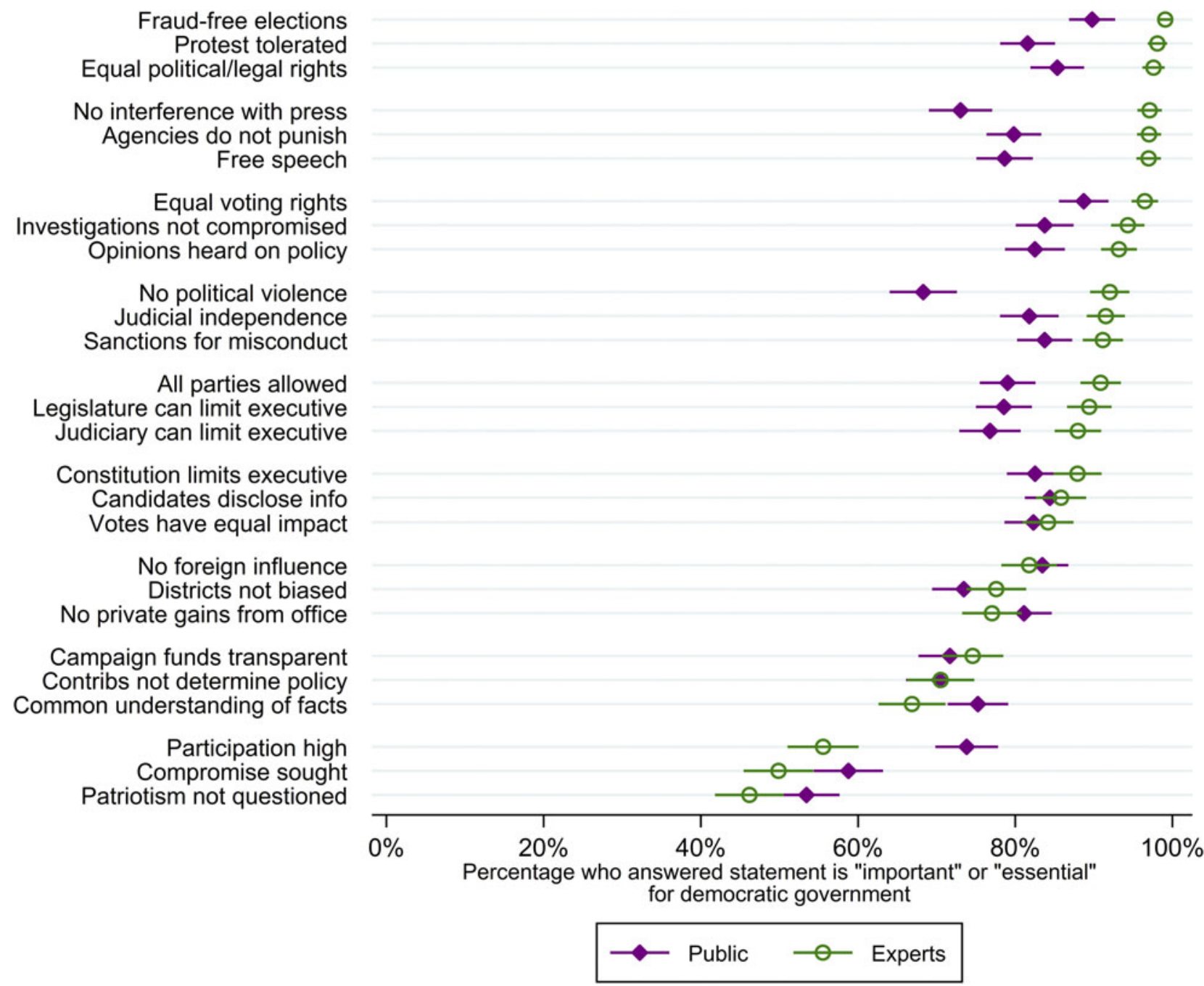

$79 \%$ public), the principle that agencies do not punish political opponents (97\% to $80 \%$ ), and for the principle of protection from political violence, which $92 \%$ of experts rank as essential or important versus only $68 \%$ of the public.

Taken together, the gaps between experts and the public over what matters most in a democracy may shed light on a puzzle that has perplexed observers of the administration: Why have events that provoked outrage from the media and other elites not generated a greater public response? A simple answer that emerges from our data is that the disparity in outrage between elites and ordinary Americans, which is lamented by many in academia and the mainstream media, tracks some of the main differences we find over democratic priorities.

For example, the First Amendment principles that are being threatened by behavior such as the president's threats to open up libel laws are not as important to the public as they are to our experts or to other elites. ${ }^{15}$ Along the same lines, only two-thirds of the public view the government's ability to thwart private actors from engaging in politically motivated violence or intimidation as important. Perhaps this is why Trump's poll numbers remained fairly steady in the wake of the violence in Charlottesville, VA, despite widespread elite condemnation of the president saying that "I think there 
is blame on both sides" and "very fine people on both sides."

Among the public, how much agreement is there on which principles of democracy matter the most? Recall the first criterion for the compound consensus in defense of democracy. It is not that citizens hold the same values as elites, or experts, but that there are values that the public broadly shares. As one approach to answering this question, we examine whether there are shared democratic principles among supporters and opponents of President Trump.

Our surveys show substantial alignment across Trump supporters and opponents on democratic priorities. Figure 3 separates respondents by whether they approve or disapprove of President Trump's job performance. The markers indicate the percentage of each group who rate each statement of principle as important or essential for democracy. The statements are listed in descending order of perceived importance among respondents overall (i.e., the percentage of Americans who rate the principle as essential or important in the population as a whole). The horizontal space between points on each principle indicates divergence between Trump supporters and opponents.

We find first that the Trump supporters and opponents are roughly aligned on the vast majority of principles. Although there are some statistical differences-opponents place a significantly higher value than supporters on 12 of the 27 principles - substantively, the differences are generally small. For 22 of 27 principles measured, the gap between Trump supporters and opponents is less than 10 percentage points. Second, with the exception of one principle (that opponents' patriotism should not be questioned), a majority in both groups ranked every principle as important or essential to democracy, suggesting some support for Weingast's first condition for selfenforcing democracy.

Still, there are some noteworthy differences between Trump opponents and Trump supporters. The greatest polarization is on principles related to elections and institutional checks and balances. First, perhaps reflecting divisions over the Russia investigation and its role in the 2016 election, Americans are split on the principle that elections must be free from foreign influence: Trump opponents exceed supporters on this principle by 16 percentage points. Trump opponents are also far more concerned about bias in electoral districts: the gap here is 13 percentage points. Their discontent likely reflects ongoing animus over prominent GOP gerrymanders in some states and a broader pattern in which Democratic seat shares lag vote shares in Congressional elections (Chen and Rodden 2013; McGann et al. 2016).

We also find relatively large gaps between Trump supporters and opponents on principles related to checks and balances and constraints on the executive branch, including judicial independence, judicial and legislative limits on the executive, and interference with the press. Many Trump supporters seem to share the president's hostility toward the media: only $65 \%$ deem a free press important for democracy (versus $80 \%$ for Trump opponents). Trump opponents in turn are far more concerned with Congress and the courts checking executive authority and with foreign influence.

The differences in values across these two groups may be more situational than intrinsic. Our survey does not allow us to examine this possibility directly, but previous polls by Pew show a clear partisan reversal over time in support for presidential power between Democrats and Republicans (Pew 2017). In 2016, under a Democratic president, $66 \%$ of Democrats said increasing presidential power was too risky, a figure that increased to $87 \%$ under President Trump. Republicans conversely became less skeptical, with $65 \%$ saying increasing presidential power was too risky in 2017 compared with $82 \%$ in 2016 .

Nevertheless, Trump supporters and opponents show roughly equal commitment to constitutional limitations on the executive branch in our survey. Fully $84 \%$ of Trump critics and $81 \%$ of Trump supporters view this core constraint on the president as important or essential for democracy. Insofar as this principle captures the broader classically liberal concept of limited government, there is some evidence that the American public still meets the first criterion for self-enforcing democracy-a nearconsensus on some core democratic principles. What about the second criterion? Is there any consensus or broad agreement on how U.S. democracy is performing?

\section{Identifying Bright Lines in American Democracy}

A societal consensus about the nature of limits on government is necessary, but not sufficient, for selfenforcing democracy. Citizens must also agree on which actions cross bright lines that should trigger a coordinated response. If they do not agree that transgressions against democratic principles are occurring, then even unanimous agreement on which priorities matter will not rein in would-be autocrats.

We begin by considering expert and overall public perceptions of U.S. democratic performance, then evaluate the prospects for a compound consensus within each group, and finally analyze differences in perceptions between Trump supporters and opponents.

Figure 4 shows the percentage of experts and the public who rated the United States as mostly or fully meeting each standard in July 2018. The statements are listed in descending order of performance ratings by experts. There is wide variation across principles in the share of experts who regard the U.S. as performing well. More than $80 \%$ of experts regard U.S. elections as open to all parties and similarly high percentages regard the rights to protest and 


\section{Figure 3 \\ Responses from Trump approvers and disapprovers to "How important are these characteristics for democratic government?"}

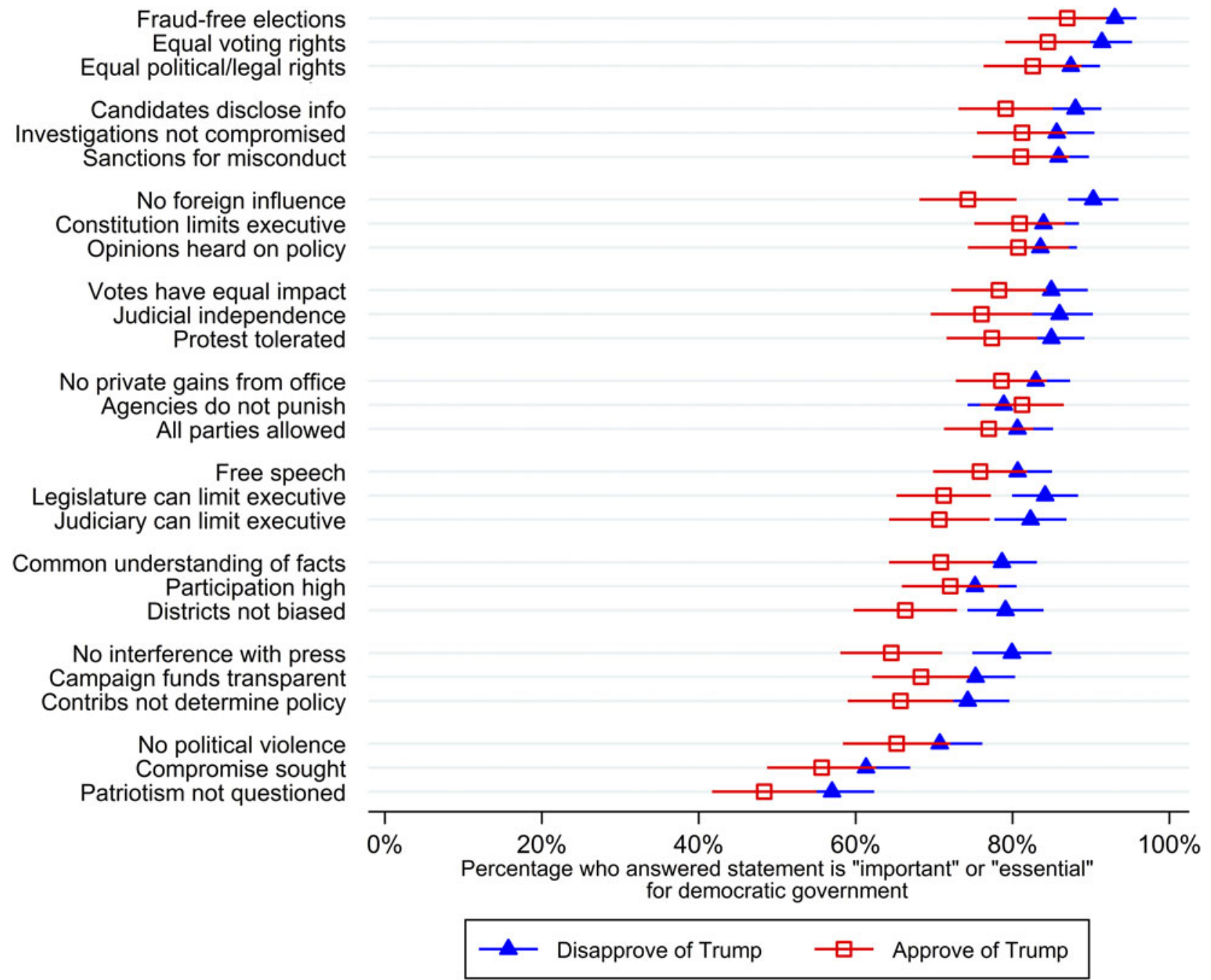

to freedom of speech to be protected. But less than $10 \%$ regard electoral districts as unbiased or perceive elected officials as seeking compromise or common understanding with opponents.

The range of performance assessments among the public is more compressed. Some of the same items are situated near the top and bottom of the performance list as for experts. ${ }^{16}$ Openness to all parties, freedom to protest, free speech, and the ability of citizens to make their opinions heard all rank high; behavioral norms, such as seeking compromise, respecting opponents, and reaching common understanding of facts, rank low. Of course, as Levitsky and Ziblatt make clear, these norms eroded well before our surveys began (Levitsky and Ziblatt 2018).
For example, in the early 1990s, Newt Gingrich's political action committee instructed Republicans to refer to Democrats as "anti-flag," "anti-family," and "traitors" (Levitsky and Ziblatt 2018, 148).

There are also noteworthy differences between our experts and the public at large. Among the public, the highest-performance item is equal voting rights $(60 \%)$, which our experts rated much lower (37\%). Conversely, only $44 \%$ of public respondents regard U.S. elections as fraud-free compared to $76 \%$ of experts. Gaps of similar magnitudes (30\% points or more) appear on the principle that no parties are barred from competing, government protects against political violence, free speech is protected, and agencies do not punish. 


\section{Figure 4}

\section{Experts and public responses to "How well does the statement describe the U.S. today?"}

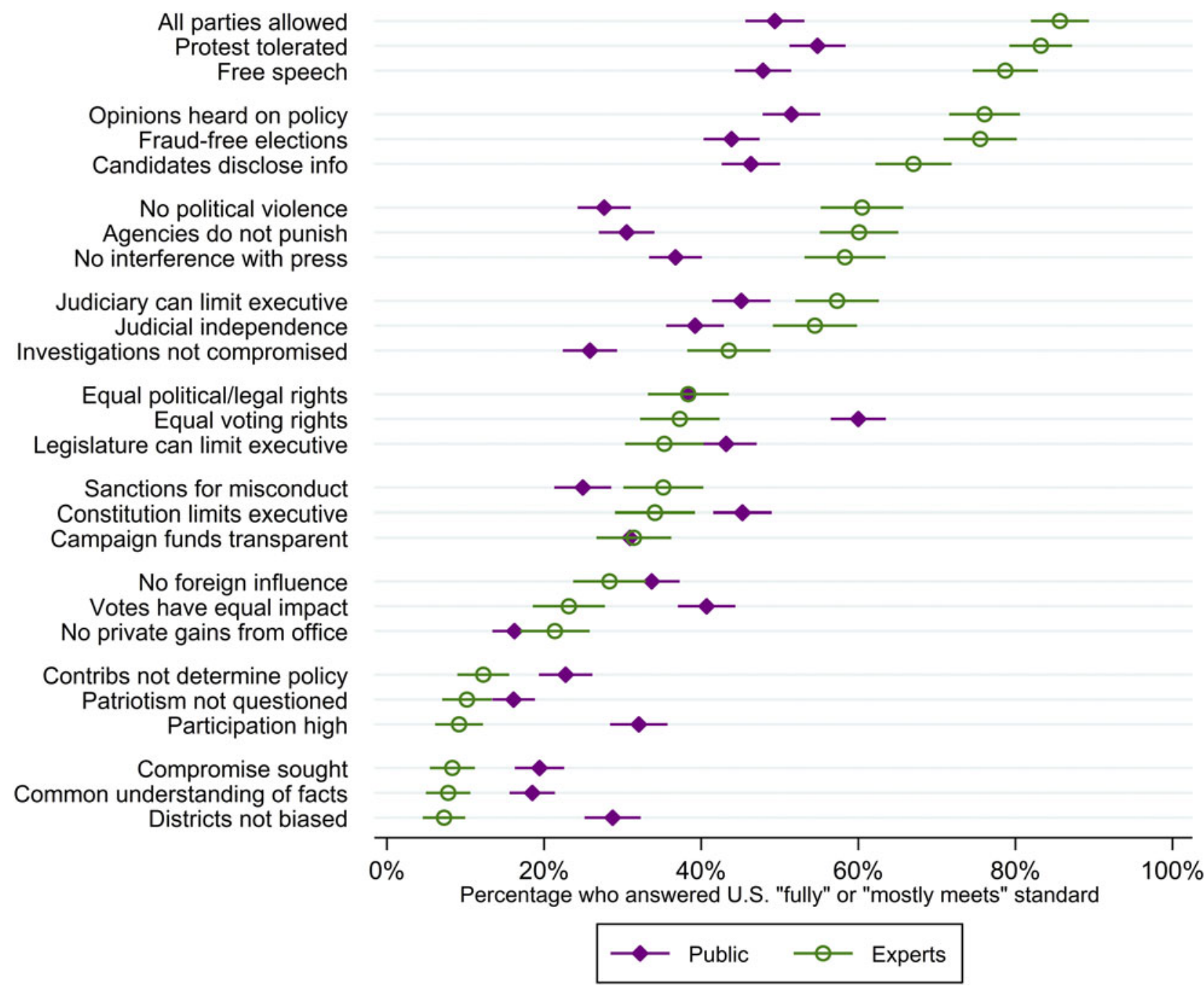

Next, we search for potential bright line principles that are both widely regarded as important and widely perceived as being violated. Our search is inspired by the core idea that a defense of democracy hinges on a compound consensus of principles. We combine information on democratic priorities from the previous section with the assessments of performance for each group across our 27 statements. In general, the data indicate that little overlap exists between potential bright line candidates for experts and the public.

For both experts (figure 5) and the public (figure 6), we plot each principle by the percentage of respondents who rate it as essential or important to democracy against the percentage who rate the U.S. as mostly or fully meeting the standard. Among both groups, we observe a positive relationship between importance and performance-they tend to rate U.S. democracy higher on principles that they value the most.

The items that fall into the lower-right sector of the plot are the most likely bright-line candidates. These are principles that are highly valued but which are widely regarded as being betrayed. They therefore represent potential candidates for a coordinated defense of democracy.

Starting with experts (figure 5), the widest gaps between importance and performance are on political/legal equality (\#3) and equality of voting rights (\#7). Equal political, legal, and voting rights are among the values that experts view as most important, but only about $40 \%$ regard the United States as meeting those standards. Two further principles that experts value, but on which they rate 


\section{Figure 5 \\ Importance versus performance: expert sample}

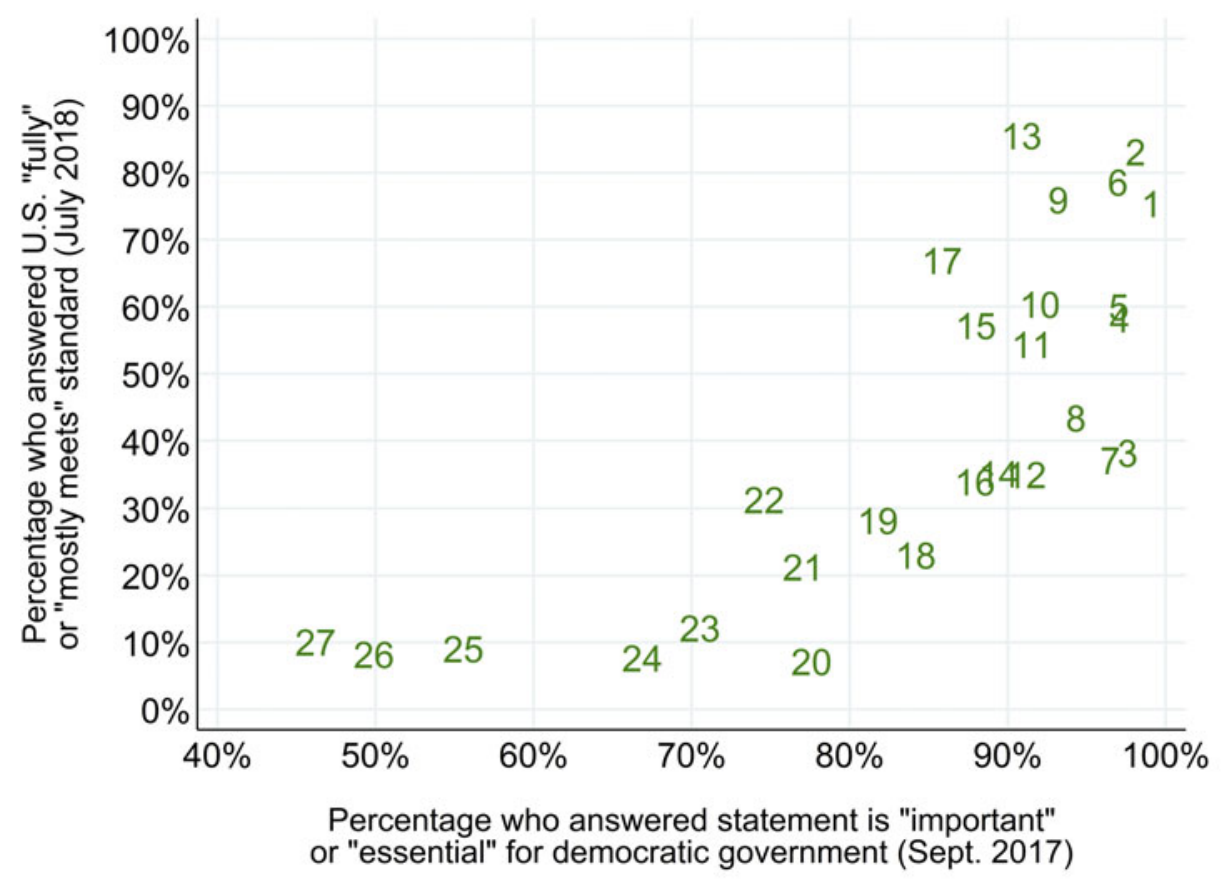

1 Fraud-free elections

2 Protest tolerated

3 Equal political/legal rights

4 No interference with press

5 Agencies do not punish

6 Free speech

7 Equal voting rights

8 Investigations not compromised

9 Opinions heard on policy

10 No political violence

11 Judicial independence

12 Sanctions for misconduct

13 All parties allowed

14 Legislature can limit executive

15 Judiciary can limit executive

16 Constitution limits executive

17 Candidates disclose info

18 Votes have equal impact

19 No foreign influence

20 Districts not biased

21 No private gains from office

22 Campaign funds transparent

23 Contribs not determine policy

24 Common understanding of facts

25 Participation high

26 Compromise sought

27 Patriotism not questioned performance to be particularly dismal, are votes having equal impact (\#18) and districts being unbiased (\#20). For experts, then, the most striking betrayals of democratic principles are on issues of equality and fairness. In addition, there is a cluster of principles related to accountability and constraints on the power of officials - sanctions for misconduct (\#12), legislative checks on the executive (\#14), and constitutional limits on the executive (\#16) - that experts widely regard as important and as areas of poor democratic performance.

Among the general public (figure 6), the strongest candidates for bright-line principles are related to political accountability, not equality or electoral fairness. Specifically, the three principles that are viewed as both important and areas of low performance are that government officials do not use public office for private gain (\#21), that they are sanctioned for misconduct (\#12), and that investigations into potential misconduct are not compromised by politics (\#8).

Breaking down public performance further to explore the degree of consensus over performance among rival groups, figure 7 presents performance evaluations for our democratic principles among respondents who approve and disapprove of President Trump. The items are listed in descending order of performance ratings among the general public. We observe that gaps between Trump supporters and opponents in perceived performance are far smaller for bright-line candidate principles (from figure 6) than among those that cluster closer to the diagonal: 5 percentage points for whether investigations are politically compromised, 6 percentage points for whether there are private gains from public office, and 12 percentage points for sanctions of misconduct. ${ }^{17}$

On many other principles, we see huge gulfs between the president's supporters and opponents. More than 30 percentage points separate the groups on no foreign influence on campaigns, equal legal and voting rights, votes counting equally, legislative limits on the executive, and no electoral district bias. Similarly, we find a 37 percentage-point performance gap for the core principle of constitutional limits on the executive.

In general, we find that the public is most polarized over U.S. democratic performance precisely on the principles that stand out as potential bright lines in the expert surveys. Thus, not only do the public and experts disagree on many democratic priorities, but the areas of greatest concern to political scientists are typically the most divisive among the public. The sole exception is sanctions for misconduct, which appears in the lower right quadrants for both experts and public.

In sum, there is little overlap between the potential bright line candidates for experts and the public. What little common ground we do find is in the area of 


\section{Figure 6 \\ Importance versus performance: public sample}

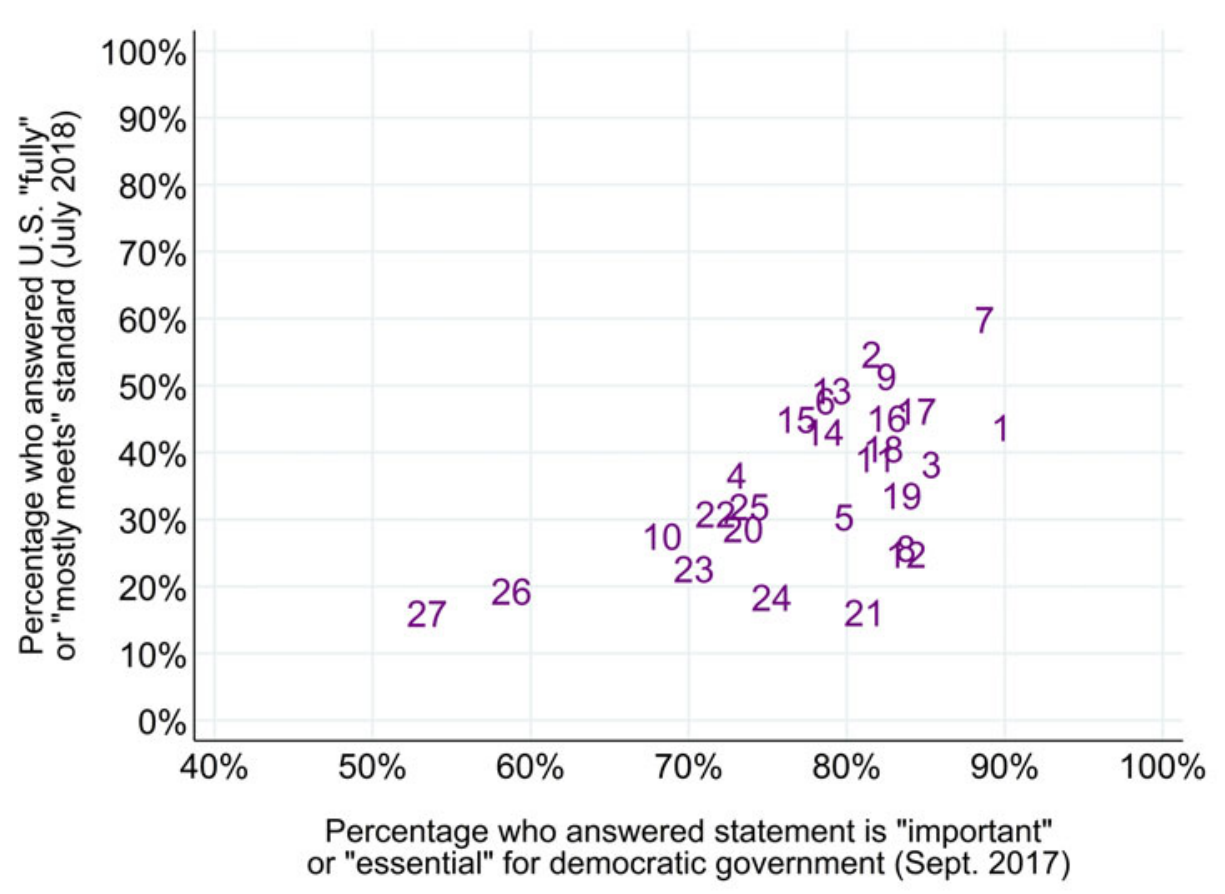

1 Fraud-free elections

2 Protest tolerated

3 Equal political/legal rights

4 No interference with press

5 Agencies do not punish

6 Free speech

7 Equal voting rights

8 Investigations not compromised

9 Opinions heard on policy

10 No political violence

11 Judicial independence

12 Sanctions for misconduct

13 All parties allowed

14 Legislature can limit executive

15 Judiciary can limit executive

16 Constitution limits executive

17 Candidates disclose info

18 Votes have equal impact

19 No foreign influence

20 Districts not biased

21 No private gains from office

22 Campaign funds transparent

23 Contribs not determine policy

24 Common understanding of facts

25 Participation high

26 Compromise sought

27 Patriotism not questioned accountability of public officials - in particular, that they are sanctioned for misconduct. Our data also reveal that divisions within the broader public over the Trump administration are translating into divisions over whether basic democratic principles are being violated. If a compound consensus across citizens is to emerge, our surveys suggest that the most promising areas of public coordination will be on principles related to the accountability of high government officials, and not around basic rights and protections, electoral fairness, or equality among citizens. ${ }^{18}$

\section{The Recent Trajectory of American Democracy}

Perceptions of democratic performance are dynamic. Over the past year-and-a-half, experts' appraisals of American democratic performance have declined. Divides among the public have also deepened, including in their views of principles of democracy that we have identified as bright-line candidates. Neither of these trends bodes well for American democracy.

Since we started conducting surveys, for instance, expert perceptions of democratic performance have declined significantly on 12 of our 27 principles. ${ }^{19}$ Figure 8 compares the percentage of expert respondents saying that the United States "mostly meets" or "fully meets" each standard when we first measured the principle in early 2017 and our survey in July $2018 .^{20}$

The path of opinions over time that our surveys reveal is broadly in line with a growing scholarly consensus that democratic erosion-as opposed to regime transitions by coup-happens piecemeal. The pace of erosion varies sharply across the range of principles. The biggest declines in our experts' views across this period was in checks on the executive. Specifically, confidence in judicial limits on the executive declined by 24 percentage points from when we initially measured them in February 2017 to July 2018; perceptions of effective legislative and constitutional checks also fell by 18 percentage points across this time period. This pattern of changes in the United States parallels that of several other countries in which democracy is under stress. The steady decline of institutional constraints on executives - in contrast to dramatic coups and power grabs-has characterized other recent cases of democratic erosion, including Hungary and Poland. In those countries, popularly elected leaders began to subvert democracy by "capturing the referees" (Levitsky and Ziblatt 2018, 81).

In the first year-and-a-half of the Trump presidency, however, experts have also become more concerned about foreign influence on elections and, alarmingly, fraud-free elections. In February 2017, fraud-free elections was the 


\section{Figure 7 \\ Responses from Trump approvers and disapprovers to "How well does the statement describe the U.S. today?"}

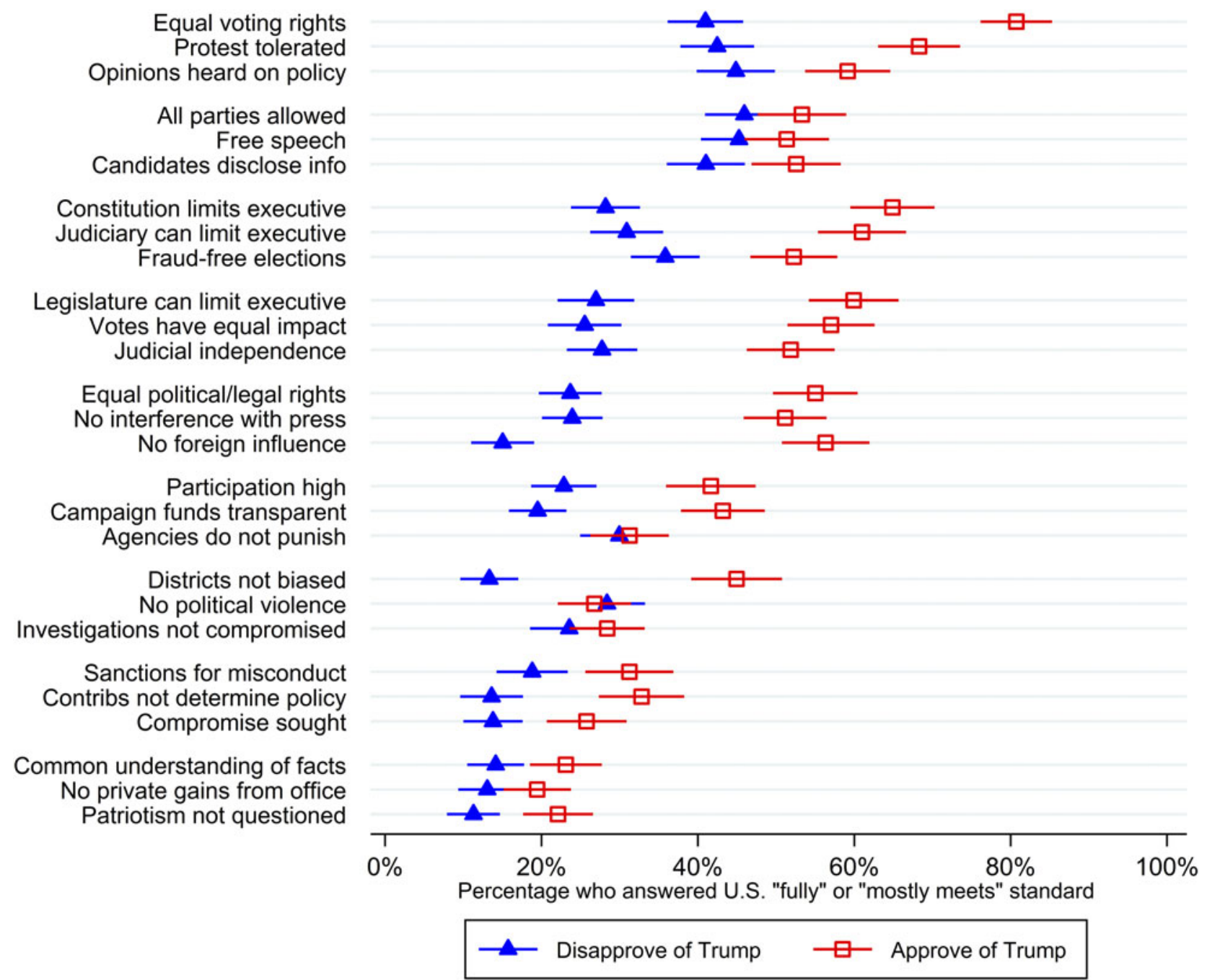

principle on which the largest share of experts, $88 \%$, viewed the United States as performing well. The number dropped in July 2018 to $76 \%$.

Figure 9 lists our principles in descending order of the change in expert assessments from Wave 3 to Wave 6 for "fully meets"/"mostly meets" responses, with $95 \%$ confidence intervals around estimates for the size of the shift. ${ }^{21}$ In this ten-month window, we observe no statistically significant improvements in ratings among experts (the principle that comes the closest is "candidates disclose information") and significant degradation on sixteen principles.

In accordance with our observations provided here, principles related to institutional checks and balances experienced the largest declines. Following a series of resignations and indictments of campaign and government officials and other startling events and policies, expert judgment in the ability of Congress or the Constitution to constrain the power of the executive and in the independence of the judiciary all eroded sharply. The percentage of experts who viewed the United States as fully or mostly meeting these standards fell by more than 20 percentage points, while confidence in judicial checks on the executive plummeted by 25 points. The period from September to July also saw declines of more than 10 percentage points in confidence that all citizens enjoy equal legal and political rights, that public officials do not make 


\section{Figure 8 \\ Expert assessments of U.S. democratic performance: Changes from first query (February or May 2017) to July 2018}

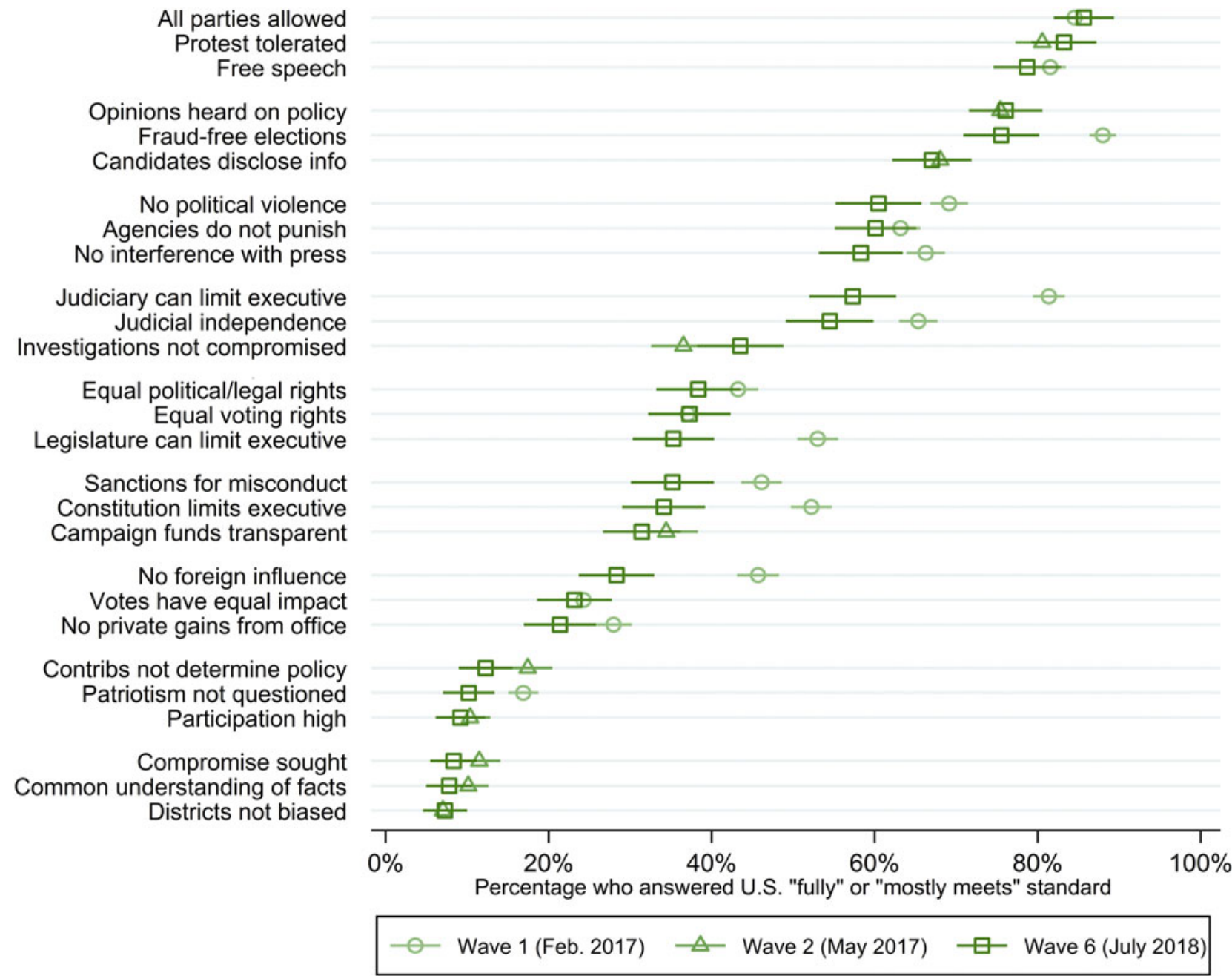

private gains from office, that elections are free from foreign influence, and that officials are sanctioned for misconduct.

Turning to the public sample, the decline in performance assessments over the same period has been even more uniform, albeit somewhat less dramatic, than among experts, as figure 10 illustrates. The portions of our public samples who see the United States as fully or mostly meeting democratic standards has declined on every democratic principle we measured. The drops are statistically significant in 22 of 27 cases. As was true of the experts, the public registered some of the biggest drops in areas related to the courts. Confidence that the courts can check the executive and that the elected branches respect judicial independence fell by 14 and 17 percentage points, respectively. Assessments of protections for free speech and against interference with the press declined by the same amounts. The public also showed substantial declines in another five areas, including fraud-free elections and equal legal and political rights.

When we separate Trump supporters and opponents by wave over the past ten months, however, the temporal dynamics are more complex. Both Trump supporters and opponents rated the performance of U.S. democracy as worse in July 2018 than in September 2017. From September 2017 to January 2018, shifts on 22 of our 27 principles were statistically indiscernible between Trump supporters and opponents, suggesting that the assessment of democratic erosion was shared even across our deepest political divide. Between January and April 
Figure 9

Changes in expert ratings of performance: September 2017 to July 2018

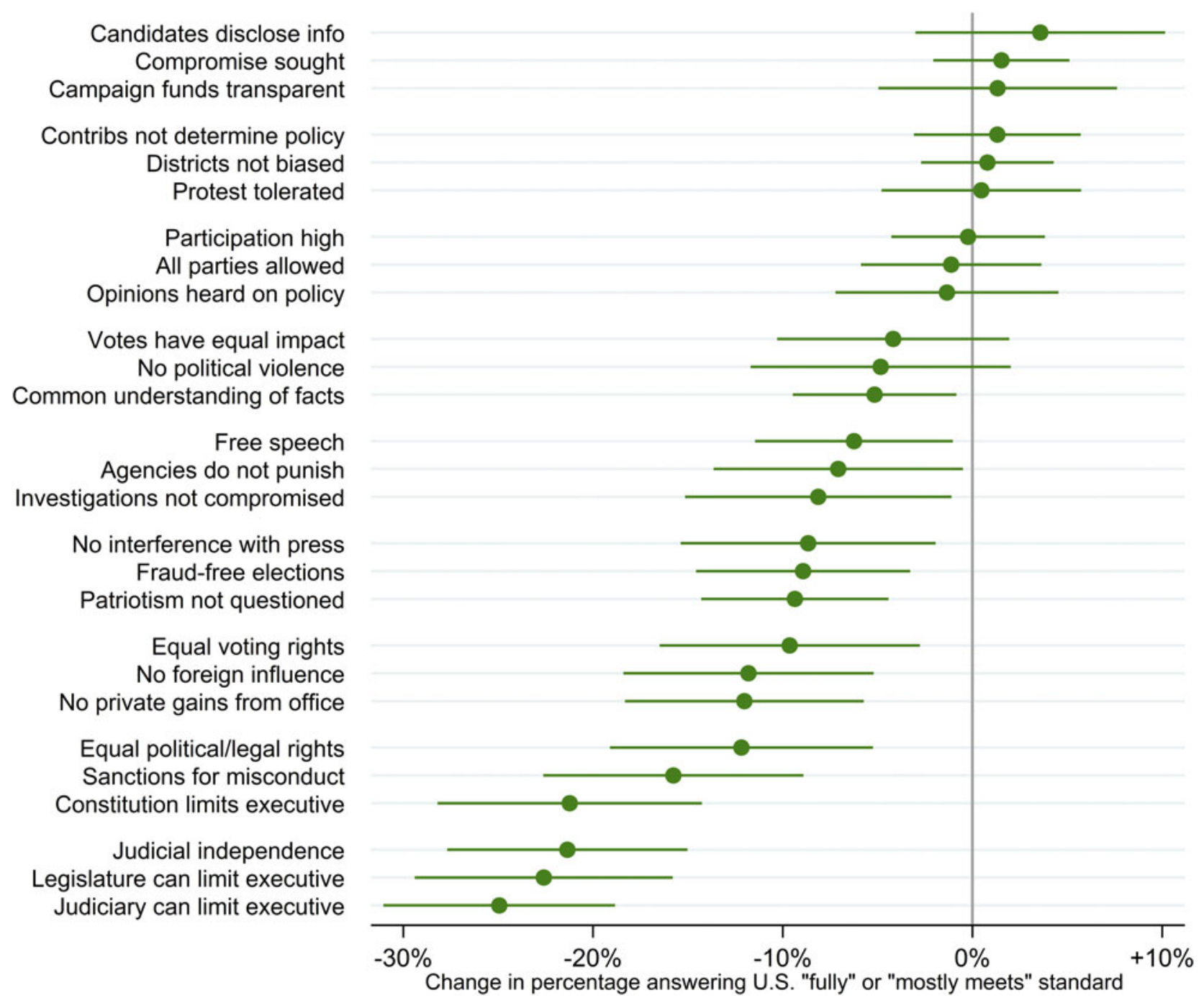

2018, the pattern of modest decline continued among both groups.

But in our July 2018 survey the partisan divide over performance sharpened considerably. In this survey wave, evaluations among Trump opponents continued to drop, most sharply for principles related to judicial independence, fraud-free elections, and protest. By contrast, Trump approvers' perceptions turned upward, registering significant jumps in performance for four principles including hot-button areas like "agencies do not punish" and "investigations not compromised." By contrast, they did not register a significant decline in performance for a single principle. As a result of these asymmetric shifts, the gap between Trump supporters and opponents over perceptions of foreign influence in elections, which had narrowed to $31 \%$ early in 2018 , spiked to $41 \%$ by July of that year. Divergence in perceptions was also particularly marked on items related to accountability, such as judicial independence, constitutional limits on the executive, and sanctions for misconduct.

\section{Conclusion}

During the past year-and-a-half, academics, journalists, public officials, and members of the public have asked urgent questions about threats to American democracy and potential sources of democratic resilience. These same questions are being posed by citizens of countries including Poland, Hungary, Turkey, the Philippines, 


\section{Figure 10}

\section{Changes in public ratings of performance: September 2017 to July 2018}

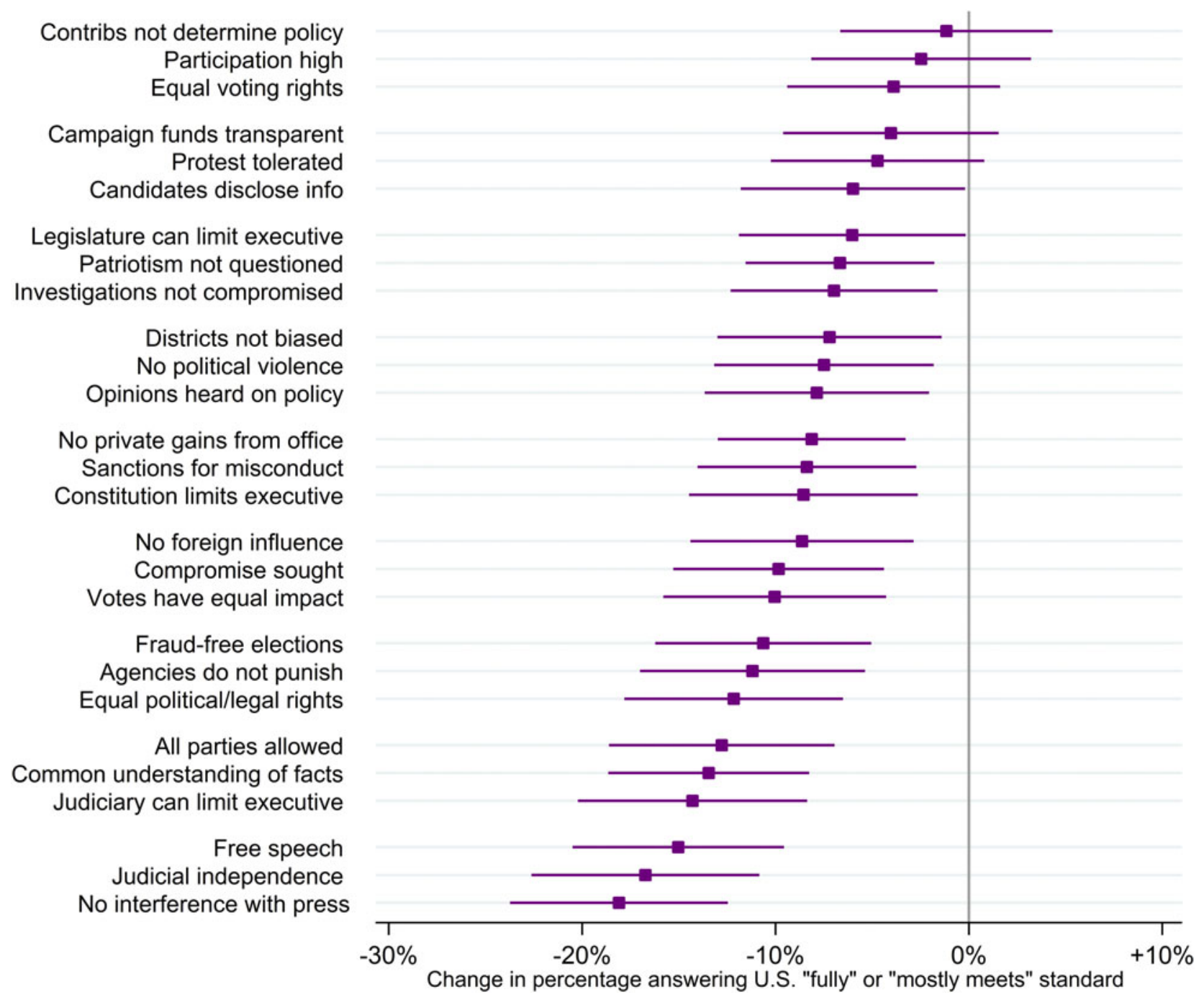

Venezuela, and Nicaragua as observers of democracy worldwide monitor signs of democratic backsliding (Diamond 2008; Diamond and Plattner 2015; Abramowitz 2018; Galston 2018; Mounk 2018; Norris and Inglehart 2018). A point of agreement in these discussions is that democracy is multidimensional and that backsliding seldom occurs across all dimensions simultaneously (Bermeo 2016; Huq and Ginsburg 2018; Levitsky and Ziblatt 2018; Posner 2018) Rather, democracy comes under threat in some areas at the same time that democratic practices persist in others. The fragmentary deterioration of democracy may be the result of strategic choices by would-be autocrats exploiting polarization (Graham and Svolik 2018; Svolik 2018) or voter uncertainty (Nalepa, Vanberg, and Chiopris 2018), trying to cling to power (Helmke 2017; Luo and Przeworski 2018), or avoid accountability (Frum 2018). Either way, if we are to understand threats to democracy and recognize them when they arise, we need disaggregated measures of what we value in democracy. The BLW surveys are an effort to provide such measures. What can they tell us after President Trump's first yearand-a-half in office?

Our surveys reveal substantial consensus on which principles are important to democracy among experts and the public. To a surprising degree, even Trump supporters and opponents largely agree about which dimensions of democracy are the most important. The top priorities are free and honest elections, the protection of equal voting, and equal political and 
legal rights. Institutional checks on executive authority and on the abuse of political power come next. Behavioral norms are valued, but they rate lower. We cannot adjudicate whether this ranking of priorities reflects a view of democracy that is "correct," either philosophically or empirically, but it is clear Americans share many values in common despite their deep polarization.

But when we turn to performance, assessments begin to diverge. Our experts remain largely confident that U.S. elections are clean and fraud-free, but the public is more skeptical. Meanwhile, over time, the public is confident that equal voting rights are effectively guaranteed, but experts are more skeptical. Over time, the gulf in performance evaluations between supporters and opponents of President Trump is growing wider. It encompasses a range of important principles, including many of those that experts think matter most. On basic equality and fairness-in legal rights, voting rights, equal ballots, and unbiased districts-Trump supporters give the United States high marks, while Trump opponents see our democracy as seriously impaired.

Weingast depicted bright lines as tripwires. When self-aggrandizing leaders crossed them, the public would spring to action to defend democracy. If bright lines require a consensus about which transgressions are critical and which more tolerable, our surveys are a source of optimism. We identify substantial areas of agreement about which transgressions matter most. But self-enforcing democracy requires more. It also needs broad agreement that leaders have transgressed against one or more important principles of democracy. By this measure, our evidence is far less encouraging.

First, our results suggest that any bright line principles are likely limited to basic matters of malfeasance and accountability, not philosophically contentious questions of equality and fairness. The BLW surveys suggest that political leaders place themselves in greater peril with the public when they engage in financial selfdealing than when they undermine the independence of the courts or threaten freedom of the press. Some might endorse accountability for officials by such means as long as the threat to democratic principles were contained. The gangster Al Capone, after all, was famously imprisoned for tax fraud. And from a positive political theory perspective, having fewer bright line candidates might facilitate the defense of democracy by providing a focal principle around which opponents can coordinate (Schelling 1960). But in a larger sense, democratic principles are most likely to be defended successfully—or not challenged at all - if transgressions against the most important democratic principles put transgressors at the greatest risk.
Moreover, our surveys show that citizens largely disagree about whether transgressions against democratic principles are occurring. President Trump's supporters and detractors are increasingly drawing conclusions about the health of our democracy that are not merely disconnected, but reflect an increasingly different understanding of our political reality itself. In that context, any lines that can be drawn by the public in defense of democracy are likely to be hazy at best.

\section{Supplementary Materials}

Tables A1-A4

To view supplementary material for this article, please visit https://doi.org/10.1017/S153759271900001X

\section{Notes}

1 The list of scholars working on the question of democratic erosion in the United States is large and fast-growing. For example, see Foa and Mounk 2016; 2017; Acemoglu 2017; Dionne, Ornstein, and Mann 2017; Lieberman et al. 2017; Snyder 2017; Fishkin and Pozen 2018; Galston 2018; Huq and Ginsburg 2018; Levitsky and Ziblatt 2018; Miller 2018a, 2018b; Mounk 2018; Norris and Inglehart 2018; Sunstein 2018; Graham and Svolik 2018; Waldner and Lust 2018; Primus 2018.

2 Foa and Mounk 2016; 2017; Ladd, Tucker, and Kates 2018. But also see Voeten 2016; Alexander and Welzel 2017; Norris 2017; Drutman, Diamond, and Goldman 2018.

3 See also Madison 1788; Lipset 1959; Almond and Verba 1963; Diamond 1999; Helmke and Levitsky 2004; and Welzel and Inglehart 2008.

4 V-Dem values are annual scores on its liberal democracy index. The bars represent the $95 \%$ highest posterior density of estimates from V-Dem's measurement model of liberal democracy.

5 The mean BLW results are as follows. 1800: 31, 1850: 35, 1900: 46, 1950: 59, 1975: 75, 1985: 77, 1995: 78, 2005: 75, 2015: 76, 2017 (September): 69, 2018 (July): 64.

6 We asked respondents to rate U.S. democracy in six separate surveys between February 2017 and July 2018. The decline we report relative to 2015 is evident in every survey.

7 The Wave 1 survey (February 2017) included 19 statements. Based on feedback from respondents and consultation with colleagues, we expanded that list to 29 statements in Wave 2 (May 2017), then reduced the set to 27 for Wave 3 (September 2017), Wave 4 (January 2018), Wave 5 (April 2018), and Wave 6 (July 2018). In total, 17 of the 27 statements were included in all four waves and all 27 were included in Waves 2 through 6 . 
8 For clarity, this list groups the principles thematically. In the surveys, the principles are not categorized or labeled. Each respondent is shown a randomly selected subset of statements. The order in which statements are presented is randomized to avoid priming or ordering effects.

9 We follow a common practice in gathering expert survey data on qualitative concepts that are otherwise difficult to measure (e.g., Steenbergen and Marks 2007; Hooghe et al. 2010; Maestas, Buttice, and Stone 2014). The resulting expert samples are substantially larger than those obtained in most political science studies (e.g., Hooghe et al. 2010), including frequently cited measures of democratic quality at the country level (e.g., Norris, Framk, and Martinez i Cona 2014; Pemstein et al. 2018). Likewise, the response rates we obtain exceed those of even highquality telephone polls of the mass public (e.g., Keeter et al. 2017). Finally, we observe a general pattern of stability over time in our longitudinal measures which suggests that our responses are not varying based on idiosyncratic changes in sample composition.

10 YouGov survey respondents were matched to a sampling frame constructed from the 2016 American Community Survey (using gender, age, race, and education). Propensity scores were then used to weight respondents to the sampling frame (using deciles based on age, gender, race/ethnicity, education, and region). Finally, post-stratification (using 2016 presidential vote, gender, age, race, and education) was used to produce the final weights for the public study.

11 In the analyses that follow, we use measures of importance from Wave 3 rather than Wave 1 because they allow us to directly compare responses from experts and the public. (Wave 1 responses from experts on importance were basically identical to Wave 3 ). Note that our results assume that experts and public have identical understandings of questions and answer categories. Future research should consider to what extent these exhibit differential item functioning and seek to address it (e.g., Pemstein et al. 2018).

12 In Wave 1, we used a ten-point scale. In Waves 2-6, we used the 0-100 scale shown above.

13 The bars represent $95 \%$ confidence intervals on estimates of the percentage who endorse either "essential" or "important."

14 As a check on robustness, we compared our reported results, which use the top two categories on the fourpoint importance and performance scales, with an alternative specification based on the top scale category only. We find that the two measures are strongly correlated. Across all survey waves, and considering experts, the public, and two subsets of the public (Trump supporters and Trump opponents), the correlations range from 0.83 to 0.93 . We therefore conclude that an alternative specification would not have substantially affected our results.

15 For example, the Authoritarian Warning Survey, which continuously polls democracy experts, found that the average threat rate to American democracy for the category of violence roughly doubled within ten days of Charlottesville (Miller 2018b).

16 A key exception is the item the public rates highest overall, equal voting rights, which experts regard as in the middle of the pack.

17 Of course, the statements we have identified as potential areas of agreement are those with low overall performance ratings, whereas polarization on performance implies that at least some respondents rate performance highly. Polarization is an inherent obstacle to forming a bright-line consensus around a democratic principle.

18 In accordance with this expectation, it is telling that Trump's approval ratings remained steady throughout the summer of 2018 despite controversies over immigrant family separation and the Helsinki summit with Russian President Vladimir Putin, and only started to dip following the split-screen indictments of his campaign manager Paul Manafort and personal lawyer Michael Cohen in late August.

19 Expert perceptions have significantly improved for only one standard: Investigations not compromised, which was first asked in May 2017 in the aftermath of President Trump's firing of F.B.I. Director James Comey.

20 Our first measurement on 17 statements took place in February 2017; on 10 others, in May 2017. The temporal point of reference is indicated by the distinct markers in figure 8.

21 To allow for direct comparison of expert and public attitudes, we anchor our changes over time to Wave 3, when we began our public surveys.

\section{References}

Abramowitz, Michael J. 2018. "Freedom in The World 2018." Democracy in Crisis. Freedom House. Retrieved September 20, 2018 (https://freedomhouse.org/sites/ default/files/FH_FITW_Report_2018_Final_SinglePage.pdf).

Acemoglu, Daron. 2017. "We Are the Last Defense against Trump." Foreign Policy, January 18. Retrived September 20, 2018 (https://foreignpolicy.com/ 2017/01/18/we-are-the-last-defense-against-trumpinstitutions/).

Almond, Gabriel and Sidney Verba. 1963. The Civic Culture: Political Attitudes and Democracy in Five Nations. Princeton, NJ: Princeton University Press. Alexander, Amy C. and Christian Welzel. 2017. "The Myth of Deconsolidation: Rising Liberalism and the 
Populist Reaction.” ILE Working Paper Series 10. Institute of Law and Economics, University of Hamburg.

Bermeo, Nancy. 2016. "On Democratic Backsliding." Journal of Democracy 27(1): 5-19.

Bright Line Watch. 2017. "Bright Line Watch Survey Report: Wave 2.” Retrieved September 20, 2018 (http:// brightlinewatch.org/blw-expert-survey-wave-2/).

Chen, Jowei and Jonathan Rodden. 2013. "Unintentional Gerrymandering: Political Geography and Electoral Bias in Legislatures." Quarterly Journal of Political Science 8(3): 239-69.

Coppedge, Michael, John Gerring, David Altman, Michael Bernhard, Steven Fish, Allen Hicken, Matthew Kroenig, Staffan I. Lindberg, Kelly McMann, Pamela Paxton, Holli A. Semetko, Svend-Erik Skaaning, Jeffrey Staton, and Jan Teorell. 2011. "Conceptualizing and Measuring Democracy: A New Approach.” Perspectives on Politics 9(2): 247-267.

Coppedge, Michael, John Gerring, Carl Henrik Knutsen, Staffan I. Lindberg, Svend-Erik Skaaning, Jan Teorell, David Altman, Michael Bernhard, M. Steven Fish, Agnes Cornell, Sirianne Dahlum, Haakon Gjerløw, Adam Glynn, Allen Hicken, Joshua Krusell, Anna Luhrmann, Kyle L. Marquardt, Kelly McMann, Valeriya Mechkova, Juraj Medzihorsky, Moa Olin, Pamela Paxton, Daniel Pemstein, Josefine Pernes, Johannes von Römer, Brigitte Seim, Rachel Sigman, Jeffrey Staton, Natalia Stepanova, Aksel Sundström, Eitan Tzelgov, Yi-ting Wang, Wig Tore, Steven Wilson, and Daniel Ziblatt. 2018. "V-Dem [Country-Year/ Country-Date] Dataset v8." Varieties of Democracy ( $V$ Dem) Project.

Dahl, Robert Alan. 1973. Polyarchy: Participation and Opposition. New Haven: Yale University Press.

Diamond, Larry. 1999. Developing Democracy: Toward Consolidation. Baltimore: The Johns Hopkins University Press.

. 2008. "The Democratic Rollback: The Resurgence of the Predatory State." Foreign Affairs 87(2): 36-48.

Diamond, Larry and Marc F. Plattner, eds. 2015. Democracy in Decline? Baltimore: Johns Hopkins University Press.

Dionne, E. J., Norman J. Ornstein, and Thomas E. Mann. 2017. One Nation after Trump: A Guide for the Perplexed, the Disillusioned, the Desperate, and the Not-yet Deported. New York: St. Martin's Press.

Drutman, Lee, Larry Diamond, and Joe Goldman. 2018. "Follow the Leader: Exploring American Support for Democracy and Authoritarianism." Democracy Fund Voter Study Group. Retrieved September 20, 2018 (https://www.voterstudygroup.org/publications/2017voter-survey/follow-the-leader).

Elkins, Zachary, Tom Ginsburg, and James Melton. 2009. The Endurance of National Constitutions. Cambridge: Cambridge University Press.
Fearon, James D. 2011. "Self-Enforcing Democracy." The Quarterly Journal of Economics 126(4): 1661-1708.

Fishkin, Joseph R. and David Pozen. 2018. "Asymmetric Constitutional Hardball." Columia Law Review 118(3). Available at https://columbialawreview.org/content/ asymmetric-constitutional-hardball/.

Foa, Roberto Stefan and Yascha Mounk. 2016. "The Democratic Disconnect." Journal of Democracy 27(3): 5-17.

- 2017. "The Signs of Deconsolidation." Journal of Democracy 27(3): 5-15.

Frum, David. 2018. Trumpocracy: The Corruption of the American Republic. New York: Harper Collins Publishers.

Galston, William. 2018. Anti-Pluralism: The Real Populist Threat to Liberal Democracy. New Haven, CT: Yale University Press.

Ginsburg, Tom and Aziz Z. Huq. 2018. How to Save a Constitutional Democracy. University of Chicago Press.

Graham, Matthew and Milan Svolik. 2018. "Democracy in America? Partisanship, Polarization, and the Robustness of Support for Democracy in the United States." Working Paper. American Politics and Public Policy Workshop, Institution for Social and Policy Studies, Yale University.

Helmke, Gretchen. 2017. Institutions on The Edge: The Origins and Consequences of Inter-Branch Crises in Latin America. Cambridge: Cambridge University Press.

Helmke, Gretchen and Steven Levitsky. 2004. "Informal Institutions and Comparative Politics: A Research Agenda." Perspectives on Politics 2(4): 725-40.

Hooghe, Liesbet, Ryan Bakker, Anna Brigevich, Catherine De Vries, Erica Edwards, Gary Marks, Rovny Jan, Marco Steenbergen, and Milada Vachudova. 2010. "Reliability and Validity of Measuring Party Positions: The Chapel Hill Expert Surveys of 2002 and 2006." European Journal of Political Research 49(5): 687-703.

Keeter, Scott, Nick Hatley, Courtney Kennedy, and Arnold Lau. 2017. "What Low Response Rates Mean for Telephone Surveys." Pew Research Center, Retrieved September 14, 2018 (http://www.pewresearch.org/ 2017/05/15/what-low-response-rates-mean-fortelephone-surveys/).

Kellstedt, Paul M. and Guy D. Whitten. 2013. The Fundamentals of Political Science Research. Cambridge: Cambridge University Press.

Ladd, Jonathan M., Joshua A. Tucker, and Sean Kates. 2018. "2018 American Institutional Confidence Poll: The Health of American Democracy in an Era of Hyper Polarization." Georgetown University Baker Center. Retrieved November 15, 2018 (https://bakercenter.georgetown.edu/aicpoll/). 
Levitsky, Steven and Daniel Ziblatt. 2018. How Democracies Die. New York: Crown Publishing.

Lieberman, Robert C., Suzanne Mettler, Thomas B. Pepinsky, Kenneth M. Roberts, and Richard Valelly. 2017. "Trumpism and American Democracy: History, Comparison, and the Predicament of Liberal Democracy in the United States." Working paper. Retrieved September 20, 2018 (https://papers.ssrn.com/sol3/ papers.cfm?abstract_id=3028990).

Lijphart, Arend. 1977. Democracy in Plural Societies: A Comparative Exploration. New Haven, CT: Yale University Press.

Lincoln, Abraham. 1838. "Lyceum Address." In The Collected Works of Abraham Lincoln. Maryland: Wildside Press LLC.

Lipset, Seymour Martin. 1959. "Some Social Requisites of Democracy: Economic Development and Political Legitimacy." American Political Science Review 53(1): 69-105.

Locke, John. 1689. Second Treatise of Government and a Letter Concerning Toleration. Oxford: Oxford University Press.

Luo, Zhaotian and Adam Przeworski. 2018. "Subversion by Stealth: Elementary Dynamics of Democratic Backsliding." Working Paper. Presented at Yale University, May 2018.

Madison, James. 1788. "The Federalist No. 48." The Federalist Papers.

Maestas, Cherie D., Matthew K. Buttice, and Walter J. Stone. 2014. "Extracting Wisdom From Experts and Small Crowds: Strategies for Improving InformantBased Measures of Political Concepts." Political Analysis 22(3): 354-73.

McGann, Anthony J., Charles Anthony Smith, Michael Latner, and Alex Keena. 2016. Gerrymandering in America: The House of Representatives, the Supreme Court, and the Future of Popular Sovereignty. Cambridge: Cambridge University Press.

Miller, Michael. 2018a. "Expert Survey on American Democracy: February 2018.” Authoritarian Warning Survey. Retrieved September 20, 2018 (https:// www.authwarningsurvey.com/single-post/2018/03/ 06/Expert-Survey-on-American-Democracy-February2018).

2018b. "Forecasting Democratic Erosion: Notes on the Authoritarian Warning Survey." Working paper. Mounk, Yascha. 2018. The People vs. Democracy: Why Our Freedom is in Danger and How to Save It. Cambridge, MA: Harvard University Press.

Nalepa, Monika, Georg Vanberg, and Caterina Chiopris. 2018. "Authoritarian Backsliding." Working paper. Retrieved December 52018 (https:// www.monikanalepa.com/uploads/6/6/3/1/ 66318923/auth_back_chicago.pdf).

Norris, Pippa. 2017. "Is Western Democracy Backsliding? Diagnosing The Risks." Working paper. Retrieved
September 20, 2018 (https://research.hks.harvard.edu/ publications/getFile.aspx?Id=1514).

Norris, Pippa, Richard W. Frank, and Ferran Martinez i Coma. 2014. "Measuring Electoral Integrity around the World: A New Dataset." PS: Political Science and Politics 47(4): 789-98.

Norris, Pipa and Ronald Inglehart. 2018. Cultural Backlash and the Rise of Populist Authoritarianism. New York: Cambridge University Press.

O’Donnell, Guillermo and Laurence Whitehead. 2009. "Two Comparative Democratization Perspectives." In Desmond King, Robert C. Lieberman, Gretchen Ritter, and Laurence Whitehead, eds. Democratization in America: A Comparative-Historical Analysis. Baltimore: Johns Hopkins University Press.

Pemstein, Daniel, Kyle L. Marquardt, Eitan Tzelgov, Yiting Wang, Joshua Krusell, and Farhad Miri. 2018. "The V-Dem Measurement Model: Latent Variable Analysis for Cross-National and Cross-Temporal Expert-Coded Data." Varieties of Democracy Institute: Working Paper 21.

Pew Research Center. 2017. "Large Majorities See Checks and Balances, Right to Protest as Essential for Democracy." Retrieved March 2, 2017 (http:// www.people-press.org/2017/03/02/large-majorities-seechecks-and-balances-right-to-protest-as-essential-for-democracy/).

Posner, Eric A. 2018. “The Dictator's Handbook, US Edition." In Can It Happen Here? Authoritarianism in America, ed. Cass Sunstein. New York: HarperCollins Publishers.

Powell, G. Bingham. 2000. Elections as Instruments of Democracy: Majoritarian And Proportional Visions. New Haven, CT: Yale University Press.

Primus, Richard. 2018. "Republic in Long-Term Perspective." Michigan Law Review Public Law and Legal Theory Research Paper Series 609.

Przeworski, Adam, Michael Alvarez, José Antonio Cheibub, and Fernando Limongi, 2000. Democracy and Development: Political Institutions and Well-Being in the World, 1950-1990. New York: Cambridge University Press.

Schelling, Thomas C. 1960. The Strategy of Conflict. Cambridge, MA: Harvard University Press.

Shugart, Matthew Soberg and John M. Carey. 1992. Presidents and Assemblies: Constitutional Design And Electoral Dynamics. New York: Cambridge University Press.

Snyder, Jack. 2017. “The Modernization Trap." Journal of Democracy 28(2): 77-91.

Steenbergen, Marco R. and Gary Marks. 2007. "Evaluating Expert Judgments." European Journal of Political Research 46(3): 347-66.

Sunstein, Cass R., ed. 2018. Can It Happen Here? Authoritarianism in America. New York: Dey Street Books. 
Svolik, Milan. 2018. "When Polarization Trumps Civic Virtue: Partisan Conflict and the Subversion of Democracy by Incumbents." Working paper. Retrieved August 30, 2018 (https://cpb-us-w2.wpmucdn.com/ campuspress.yale.edu/dist/6/1038/files/2018/09/ polarization_manuscript-2ex9y63.pdf)

Voeten, Erik. 2016. "Are People Really Turning Away From Democracy?” Working paper. Retrieved December 15, 2016 (https://papers.ssrn.com/sol3/ papers.cfm?abstract_id=2882878).
Weingast, Barry R. 1997. "The Political Foundations of Democracy and the Rule of the Law." American Political Science Review 91(2): 245-63.

Welzel, Christian and Ronald Inglehart. 2008. "The Role of Ordinary People in Democratization." Journal of Democracy 19(1): 126-40.

Waldner, David and Ellen Lust. 2018. "Unwelcome Change: Coming to Terms with Democratic Backsliding." Annual Review of Political Science 21: 93-113. 